\title{
1 Gazing at cell wall expansion under a golden light
}

Bénédicte Charrier ${ }^{1} *$, Hervé Rabillé ${ }^{1}$, Bernard Billoud ${ }^{1}$

${ }^{1}$ UMR8227, CNRS-Sorbonne Université. Station Biologique, Place Georges Teissier, 29680 Roscoff, France.

*Correspondence: benedicte.charrier@sb-roscoff.fr (B. Charrier)

http://www.sb-roscoff.fr/en/team-morphogenesis-macroalgae-mma

Keywords: Brown algae, Cell wall, Mechanics, Evolution, Polysaccharides, Remodelling

In plants, cell growth is constrained by a stiff cell wall - at least this is the way textbooks usually present it. Accordingly, many studies have focused on the elasticity and plasticity of the cell wall as prerequisites for expansion during growth. With their specific evolutionary history, cell wall composition and environment, brown algae present a unique configuration offering a new perspective on the involvement of the cell wall - viewed as an inert material with yet intrinsic mechanical properties - in growth. In light of recent findings, we explore here how much of the functional relationship between cell wall chemistry and intrinsic mechanics on the one hand, and growth on the other hand, has been uncovered in brown algae.

\section{Cell wall expansion: does the known matter really matter?}

The most common paradigm of plant cell growth involves the generation of tensile stress, mainly due to cell turgor, causing the cell wall to yield. In response to this tensile stress, cell volume increases due to the influx of water and cell wall biosynthesis is activated, maintaining cell wall thickness and preventing disruption [1]. This increase in volume tends to attenuate turgor, but the ongoing re-establishment of the intracellular osmotic potential maintains the tensile stress. These dynamic processes lead to continuous growth - but only if the cell wall is able to yield. Many 
31 studies in land plants, fungi, green and yellow-green algae have attempted to link the intrinsic

32 chemical and mechanical (elasticity, plasticity, as assessed by short-term experiments) features of 33 the cell wall to its potential for growth (a potentially long-term process). Seemingly intuitive, this 34 relationship can be tested using current technologies that allow the acquisition of quantitative mechanical data. However, it remains plausible that cell wall growth does not necessarily involve cell wall resistance countering strong tensile stress, like two players pulling a rope in opposite

\section{Uncoupling cell wall growth from the intrinsic mechanical properties of the cell wall}

Growth implies an irreversible deformation of the cell wall, and thus implicitly involves the plasticity of the material that makes up the cell wall. By definition, irreversibility is detected after the growth event has taken place. Hence, growth can be a two-step process in which the cell wall yields according to the elastic nature of the material and this deformation is simultaneously made irreversible through consolidation of cell wall material [2]. Or, growth can be a one-step process based on the plastic nature of the cell wall material, for which deformation itself is irreversible and deformation takes place only when the applied stress exceeds a given threshold (the 'yield threshold'). These two cases rely on the intrinsic mechanical properties of the cell wall taken as a physical material (Figure 1A) in which growth is made possible only when the mechanical properties of the cell wall are modified. A third mechanism is characterised by cell wall remodelling without modifying the intrinsic mechanical properties of the cell wall (Figure 1B). In this process, yielding is made possible - or is enhanced - due to modification in the organisation of the cell wall material, and not necessarily in its actual chemical composition. These two mechanical properties, i.e. (1) intrinsic mechanical properties (namely elasticity and/or plasticity) and (2) remodelling can theoretically be involved in cell wall growth in all organisms. 
62 Experimentally, assessing the intrinsic mechanical properties of the cell wall is easier than 63 deciphering the process by which the cell wall remodels. In particular, many available techniques can quantify cell wall elasticity, such as indentation using atomic force microscopy (AFM), or stretching [3,4] (Table 1). As a result, reports abound on the close relationship between growth and the intrinsic elasticity of the cell wall (e.g., recently in fungi [5]). Emergence and growth of buds in the Arabidopsis apical meristem have been correlated with an increase in elasticity [6], in a process similar to that occurring in the tip-growing pollen tube, in which elasticity continuously decreases from the tip to $20 \mu \mathrm{m}$ behind it [7]. Similar observations have been reported in fungal hyphae [8], but far away from the growth zone. However, the technical flaws pertaining to AFM techniques (Table 1) recently highlighted by D. Cosgrove [9] raises de facto some issues about the thus far demonstrated role of intrinsic elasticity in growth. At the cellular level, physical measurements of the cell wall ability to yield, which requires quite large cell wall surfaces (e.g., Chara and Vaucheria, [10]), are rarely performed to confirm AFM data, especially in living cells. Nonetheless, in some cases, cellular expansion in response to hypo-osmotic treatments has confirmed the overlapping patterns of cell wall elasticity and cell growth [11].

When neither of the two intrinsic mechanical properties discussed above seem to be involved, and when growth is shown to require heat and/or living cells, then cell wall remodelling factors releasing the load-bearing bonds are introduced as necessary factors for the cell wall to yield

80 (Figure 1B). The extent to which remodelling is separate from the intrinsic mechanical properties 81 has been debated and most likely depends on the cell, species and growth mode (diffuse or localised, e.g., at the tip of an apical cell). Since the 1892 demonstration that ascomycete Peziza

83 hyphae bursts at the base of the apex where growth is slower and not at the tip where growth is 84 higher [12], it has been clear that the most deformable positions do not necessarily correlate with actively growing zones. Similarly, stiffness does not correlate with slow-growing cells either. The inner layer of the cell wall of Aspergillus spores is extremely stiff (elastic modulus E up to 30 $87 \mathrm{GPa}$; [13]); nevertheless, this is where bud emergence takes place to initiate hyphal growth. 88 Bamboo culms grow very fast via cell elongation at the base of internodes (cumulative growth 89 rate of $\sim 30 \mathrm{~mm} \cdot \mathrm{h}^{-1}$ ), where secondary cell wall biosynthesis and lignification, initiated before the 90 cessation of cell elongation, lead to very stiff cell walls ( $\mathrm{E} \sim 20 \mathrm{GPa}$; [14]). This cell wall is 9110,000 times stiffer than the cell wall of the pollen tube which has an elongation rate 100 times 92 slower $\left(\sim 300 \mu \mathrm{m} \cdot \mathrm{h}^{-1}\right)$. Beyond these simple observations, experimental data have since 
93 demonstrated further this lack of correlation between the intrinsic mechanical properties and 94 growth in land plant cell walls ([15], reviewed by [16]).

95 Brown algae are macroscopic, multicellular organisms displaying many differences with their land counterparts. Their ancestor likely diverged > 1.6 Mya [17], a period during which three endosymbiotic events took place [18], leading to organisms with specific cellular and genomic features [19,20]. More importantly here, their environment features mechanical properties completely different to those experienced on land. When immersed, most of their growing cells are permanently exposed to seawater moving at a density more than 1000 times greater than the air, generating forces similar to hurricane-forces every few seconds [21]. Wave-swept animals develop very stiff bodies to resist these forces, but seaweeds opted for a different strategy: their stiffness is $\sim 100-1000$ times lower than land plants, and they have high extensibility. In addition, due to periodic tides in their natural environment, brown algae are usually exposed to a large range of osmotic variations due to dehydration at one extreme of the range and to flooding with rainwater at the other. When immersed in pure water or $2 \mathrm{M} \mathrm{NaCl}$ (corresponding to four times the seawater concentration), cells of the brown alga Ectocarpus respectively expand by up to $70 \%$ (in pure water) and shrink down to $35 \%$ of their volume (corresponding to $40 \%$ of their surface area; unpublished personal data). In comparison, cells of the tomato shoot apical meristem expand and shrink by about $9 \%$ in surface area [11].

Nevertheless, there is a disconnection between these intrinsic mechanical properties of the cell wall and growth potential (Figure 1C). For example, in the apical cell of the filamentous brown alga Ectocarpus, treatment with the actin-depolymerising drug latrunculin B promotes doubled growth in width, but fully blocks cell swelling in the same axis after immersion in halfconcentrated seawater (unpublished personal data). This strongly suggests that in these conditions, the underlying mechanics required for growth is distinct from the elasticity/plasticity involved in rapid volume changes, regardless of the exact role of actin in this process. Similar cell wall stiffening has been observed in the pollen tube in response to cytochalasin D, another actindestabilising drug [22], but the morphological effects are less pronounced and this result was attributed to micro-indentation artefacts due to the dome shape. This explanation is excluded when elasticity is measured from changes in cell volume and when deformability can be directly measured in the plane of the cell wall, as performed in the case of Ectocarpus.

\section{Cell wall growth: demystifying polysaccharide chemistry}


125 Cell walls are a mixture of compounds whose relative organisation is still obscure, especially in 126 brown algae. At the chemical level, $>80 \%$ of brown algal cell wall is chemically different from 127 land plant cell walls (Table 2). As in land plants, polysaccharides are the main components, but 128 they are represented by large and rare cellulose microfibrils immersed in abundant alginates $129(\sim 40 \%)$ and sulphated fucans $(\sim 40 \%)([23]$, Figure 2$)$. That results in cell walls with a much lower 130 degree of crystallinity compared to land plants, and altogether these major differences hinder any 131 reliable transposition between the two groups of organisms.

132 In the context of growth, a link between cell wall chemical composition and its propensity to 133 expand is intuitively natural. Fungal cell wall biosynthesis mutants are impaired in cell growth 134 [24] and the level of pectin methylesterification in angiosperm pollen tubes is directly 135 proportional to growth rate [25]. However, the role of alginates in growth, and especially of 136 mannuronans which are described as 'soft' components in in vitro studies [26], has no support 137 thus far. In the brown alga Sargassum, the position of new buds is not correlated with a specific 138 spatial pattern of alginates [27], and no correlation has been found between the active growth site 139 in the rhizoid of the embryo of the brown alga Fucus and the presence of soft or stiff alginates 140 [28].

141 In brown algae, can the polysaccharide composition control the intrinsic mechanical properties of 142 the cell well, if not its expansion? 'Soft' mannuronan alginates have been shown to be 143 preferentially extracted from organs with flexible properties, whereas stiff guluronan alginates 144 [26], which form in vitro complexes with calcium as pectins do (Figure 2), have been extracted 145 from load-bearing organs exposed to drag forces (e.g., kelp stipes in environments exposed to waves [29], and references therein). However, completely contrasting observations have also been reported. Miller et al. [30] found that the highest levels of the stiff guluronans were measured in the most mucilaginous and flexible seaweeds of their study, regardless of their age. This echoes similar observations made in the Arabidopsis shoot apical meristem, where an increase in pectin demethylesterification co-locates with an increase in elasticity [6], but stiffens the cell wall in the

151 shanks of the pollen tube [25]. Therefore, these examples illustrate that, in brown algae as in land 152 plants, the complexity of the mechanics of the cell wall, and moreover of growth cannot be 153 reduced to the presence or absence of a single, or even a handful of polysaccharides. Knowledge 154 of the complete interacting molecular network is the first step before translating chemical 155 composition into mechanics [31]. Even in land plants where most of the cell wall chemical components have been identified and where there is a comprehensive set of positional patterns of 
157 cell wall components (e.g., along the tip-growing pollen tube; [32]), the interactive network 158 remains vague and incomplete [33], preventing any simple, straightforward conclusion as to the 159 role of these compounds in growth. Other factors such as the degree of hydration, the ion 160 concentration or the rate of degradation of polysaccharides are alternative driving forces in cell 161 growth (as discussed in [34,35]).

162 As a result, attempts to piece together partial knowledge lead to complex scenarios, such as those 163 featured for pollen tube growth, where differential and often counter-intuitive gradients of factors 164 including calcium concentration and pectin-methylesterase enzyme (PME) activities, are squeezed 165 into a possible mechanism of tip growth [36,37]. However, the different biological contexts call

166 for putting all the cards back on the table. In brown algae, alginate stiffness is described as 167 depending directly on the calcium concentration, but this relationship degenerates when calcium 168 concentration is 10 times that of the seawater [38], a situation that can be reached locally in muro 169 in emerged thalli, especially in poro-elastic cell walls [32]. As for PME, recent studies suggest 170 that the control of methylesterification (including both PME activity and a PME inhibitor, PMEI) 171 is especially important for the fast growth of angiosperm pollen tubes, and less determinate in 172 gymnosperms in which the gradients of esterified pectins are less pronounced and PMEI is absent 173 [37]. Furthermore, studies of growth mechanisms in more basal green cells, such as in the 174 charophyte alga Chara, argue that the role of PME as described in the pollen tube may be limited 175 to the more recently evolved green plants [14]. This is just a sign of the diversity of mechanisms 176 that may be encountered in organisms whose phylogenetic position is distant to the most studied 177 plant models, and an indication that our understanding of their role in plant cell growth lato sensu 178 should mature with future evo-devo studies.

180 Interpretation of results becomes even more complex when cell wall polysaccharides of different 181 natures compensate each other. In brown algae, degradation of alginates leads to a stiffer cell wall 182 unable to expand in response to hypo-osmotic shock, suggesting that alginates are necessary to 183 ensure intrinsic cell wall elasticity (unpublished personal data). However, a closer look shows that 184 this decrease in elasticity is due to an over-accumulation of cellulose at the sub-cellular location 185 where growth takes place. The high stiffness of cellulose (E of up to $175 \mathrm{GPa}$; [39], compared 186 with alginate with value of $\mathrm{E} \sim$ a few $\mathrm{kPa}$, [40] and pectin $\mathrm{E}$ of up to $1 \mathrm{MPa}$; [41]) easily accounts 187 for the observed decrease in cell wall extensibility. Similar cellulose accumulation occurred 188 during the over-growth of the apical cell in response to LatB treatment, showing that despite its 
189 high stiffness, cellulose does not hinder growth. On the contrary, in plants, cellulose has also the 190 potential to promote growth [42]. This uncoupling between the role of cellulose in both the 191 intrinsic mechanical properties and cell wall expansion echoes the recent finding that growth and 192 cellulose biosynthesis are regulated by distinct pathways in the Arabidopsis hypocotyl [43]. 193 Uncoupling metabolic activity from light-dependent circadian rhythms demonstrated that cell 194 wall biosynthesis is controlled by the former and growth by the latter. Furthermore, cellulose synthases (GT2 family of glucosyl-transferases), as defined from sequence similarity, may not synthesise only cellulose but instead produce mixed-linkage polysaccharides (MLGs) or even new polysaccharides, such as arabinoglucan recently shown in the moss Physcomitrella [44]. These results show that the links between cell growth and cellulose and/or cellulose synthase genes - as

199 a proxy for cellulose accumulation - are not direct. Clearly, there is a need to revisit the 200 assumption that the presence of stiff components in the cell wall prevents or mitigates its 201 expansion.

202 So, are polysaccharides more than just inert structural components subjected to the activities of 203 remodelling proteins during growth? Several distinct remodelling mechanisms have been 204 described in land plants, green algae and fungi. In Chara, the ongoing delivery of new cell wall 205 components modifies the dynamics of pectate- $\mathrm{Ca}^{2+}$ complexes formed in muro (the so-called 206 'pectate distortion' mechanism [14]), thereby remodelling the cell wall. However, proteins are 207 central factors in most of the remodelling processes described so far. In land plants, the 208 xyloglucan-endo-transglycosylases-hydrolases (XTH) participate in cell wall expansion through 209 hemicellulose cutting and joining [45] and expansins modify hemicellulose-mediated bonds 210 between stiff cellulose fibres ([4] and subsequent papers). Any resulting gaps are filled with 211 freshly made or delivered material, allowing the overall expansion of the local cell wall. In fungi, 212 radical coupling catalysed by an oxidase occurs between the cell wall polymers 213 glucosaminoglycan and beta-glucan [12].

214 Brown algal cell walls have been shown to contain proteins in significant amounts ( $>5 \%$ of the 215 cell wall biomass; $[23,46])$ and with a high diversity (> 900 different proteins secreted in brown 216 algae [47]). Interestingly, in brown algae, none of these proteins share similarity with expansin, 217 PME or even cellulase (Table 2; from genomic analysis; [48]). Domains of cell wall remodelling 218 proteins have been identified among secreted proteins (e.g. carbohydrate binding module CBM32 219 interacting with alginates; [47]) making them prime candidates for remodelling factors [49]. In 220 addition, families of secreted brown algal proteins are specific (e.g., alginate C5-epimerases) or 
221 expanded (vanadium haloperoxidase, metalloproteinases) relative to those of land plants [47,50].

222 Finally, signalling proteins such as the Notch-Domain proteins, previously thought to be specific 223 to animal cells, are over-represented in brown algal cell walls [47]. Therefore, in light of recent 224 data, our current understanding, which still requires more knowledge on cell wall molecular 225 composition and organisation in dynamic conditions, is that brown algae developed a specific 226 secretome for cell wall remodelling.

\section{Concluding remarks and future prospects}

229 Work on non-conventional models phylogenetically distant from land plants gives the opportunity 230 to unveil the existence of alternative mechanisms of growth. In these organisms (and previously 231 noted in land plants and green algae [51]), the causal relationship between cell wall growth and 232 intrinsic cell wall mechanical properties, or cell wall growth and cell wall chemical composition, 233 are not obvious. Furthermore, the difference in growth strategies may also be related to the type of 234 organ (e.g., shoot apical meristem or pollen tube in land plants, internodes in green alga Chara), 235 its growth mode (respectively tip-growing or diffuse) or its growth dynamics.

236 The first results obtained in brown algae show that the distribution of cell wall polysaccharide 237 determinants is not easily linked to the cell growth pattern, and that the intrinsic mechanical 238 properties may not systematically correlate with growth potential. This leaves plenty of room for 239 alternative processes, including cell wall remodelling with no alteration of the intrinsic 240 mechanical properties. However, due to the very different composition and organisation of the 241 cell walls in green plants and brown algae, the molecular toolkits of the remodelling machinery 242 are likely fundamentally different. Beyond the potential conservation of molecular factors, 243 cellular and biomechanical studies carried out in brown algae will most likely lead to 244 breakthroughs in alternative mechanisms of cell wall remodelling.

\section{Acknowledgement}

247 We thank Cécile Hervé for fruitful discussion about the cell wall composition.

\section{References}

1 Davì, V. et al. (2018) Mechanosensation Dynamically Coordinates Polar Growth and Cell Wall Assembly to Promote Cell Survival. Dev. Cell 45, 170-182.e7 
2 Fayant, P. et al. (2010) Finite Element Model of Polar Growth in Pollen Tubes. Plant Cell 22, $2579-2593$

3 Ahmad, I.L. and Ahmad, M.R. (2014) Trends in characterizing single cell's stiffness properties. Micro Nano Syst. Lett. 2,8

4 Cosgrove, D.J. (1993) Wall extensibility: its nature, measurement and relationship to plant cell growth. New Phytol. 124, 1-23

5 Haneef, M. et al. (2017) Advanced Materials From Fungal Mycelium: Fabrication and Tuning of Physical Properties. Sci. Rep. 7,

6 Peaucelle, A. et al. (2011) Pectin-Induced Changes in Cell Wall Mechanics Underlie Organ Initiation in Arabidopsis. Curr. Biol. 21, 1720-1726

7 Geitmann, A. and Parre, E. (2004) The local cytomechanical properties of growing pollen tubes correspond to the axial distribution of structural cellular elements. Sex. Plant Reprod. 17, 9-16

$8 \mathrm{Ma}$, H. et al. (2005) Surface ultrastructure and elasticity in growing tips and mature regions of Aspergillus hyphae describe wall maturation. Microbiol. Read. Engl. 151, 3679-3688

9 Cosgrove, D.J. (2016) Catalysts of plant cell wall loosening. F1000Research 5,

10 Mine, I. et al. (2003) Fine structure of spermatial surface in the red alga Antithamnion nipponicum (Rhodophyta). Phycol. Res. 51, 109-117

11 Kierzkowski, D. et al. (2012) Elastic Domains Regulate Growth and Organogenesis in the Plant Shoot Apical Meristem. Science 335, 1096-1099

12 Wessels, J.G.H. (1988) A steady-state model for apical wall growth in fungi. Acta Bot. Neerlandica 37, 3-16

13 Zhao, L. et al. (2005) Assessment of Elasticity and Topography of Aspergillus nidulans Spores via Atomic Force Microscopy. Appl. Environ. Microbiol. 71, 955-960

14 Boyer, J.S. (2016) Enzyme-Less Growth in Chara and Terrestrial Plants. Front. Plant Sci. 7,

15 Park, Y.B. and Cosgrove, D.J. (2012) Changes in Cell Wall Biomechanical Properties in the Xyloglucan-Deficient xxt1/xxt2 Mutant of Arabidopsis. Plant Physiol. 158, 465-475

16 Cosgrove, D.J. (2018) Diffuse Growth of Plant Cell Walls. Plant Physiol. 176, 16-27

17 Baldauf, S.L. (2008) An overview of the phylogeny and diversity of eukaryotes. J. Syst. Evol. $46,263-273$

18 Stiller, J.W. et al. (2014) The evolution of photosynthesis in chromist algae through serial endosymbioses. Nat. Commun. 5, 
19 Charrier, B. et al. (2008) Development and physiology of the brown alga Ectocarpus siliculosus: two centuries of research. New Phytol. 177, 319-332

20 Cock, J.M. et al. (2010) The Ectocarpus genome and the independent evolution of multicellularity in brown algae. Nature 465, 617-621

21 Denny, M. and Gaylord, B. (2002) The mechanics of wave-swept algae. J. Exp. Biol. 205, $1355-1362$

22 Zerzour, R. et al. (2009) Polar growth in pollen tubes is associated with spatially confined dynamic changes in cell mechanical properties. Dev. Biol. 334, 437-446

23 Deniaud-Bouët, E. et al. (2014) Chemical and enzymatic fractionation of cell walls from Fucales: insights into the structure of the extracellular matrix of brown algae. Ann. Bot. 114, $1203-1216$

24 Uchiyama, H. et al. (2018) The effects of gene disruption of Kre6-like proteins on the phenotype of $\beta$-glucan-producing Aureobasidium pullulans. Appl. Microbiol. Biotechnol. 102, $4467-4475$

25 Parre, E. and Geitmann, A. (2005) Pectin and the role of the physical properties of the cell wall in pollen tube growth of Solanum chacoense. Planta 220, 582-592

26 Braccini, I. et al. (1999) Conformational and configurational features of acidic polysaccharides and their interactions with calcium ions: a molecular modeling investigation. Carbohydr. Res. 317, 119-130

27 Linardić, M. and Braybrook, S.A. (2017) Towards an understanding of spiral patterning in the Sargassum muticum shoot apex. Sci. Rep. 7, 13887

28 Torode, T.A. et al. (2016) Dynamics of cell wall assembly during early embryogenesis in the brown alga Fucus. J. Exp. Bot. 67, 6089-6100

29 Jothisaraswathi, S. et al. (2006) Seasonal studies on alginate and its composition II: Turbinaria conoides (J.Ag.) Kütz. (Fucales, Phaeophyceae). J. Appl. Phycol. 18, 161

30 Miller, I.J. (1996) Alginate composition of some New Zealand brown seaweeds. Phytochemistry 41, 1315-1317

31 Shtein, I. et al. (2018) Plant and algal structure: from cell walls to biomechanical function. Physiol. Plant. 164, 56-66

32 Chebli, Y. et al. (2012) The Cell Wall of the Arabidopsis Pollen Tube-Spatial Distribution, Recycling, and Network Formation of Polysaccharides. Plant Physiol. 160, 1940 
33 Mollet, J.-C. et al. (2013) Cell Wall Composition, Biosynthesis and Remodeling during Pollen Tube Growth. Plants 2, 107-147

34 Peaucelle, A. et al. (2008) Arabidopsis phyllotaxis is controlled by the methyl-esterification status of cell-wall pectins. Curr. Biol. CB 18, 1943-1948

35 Bidhendi, A.J. and Geitmann, A. (2016) Relating the mechanics of the primary plant cell wall to morphogenesis. J. Exp. Bot. 67, 449-461

36 Bosch, M. and Hepler, P.K. (2005) Pectin Methylesterases and Pectin Dynamics in Pollen Tubes. Plant Cell 17, 3219-3226

37 Wallace, S. and Williams, J.H. (2017) Evolutionary origins of pectin methylesterase genes associated with novel aspects of angiosperm pollen tube walls. Biochem. Biophys. Res. Commun. 487, 509-516

38 Cuadros, T.R. et al. (2012) Mechanical properties of calcium alginate fibers produced with a microfluidic device. Carbohydr. Polym. 89, 1198-1206

39 Geitmann, A. (2006) Experimental approaches used to quantify physical parameters at cellular and subcellular levels. Am. J. Bot. 93, 1380-1390

40 Larsen, B.E. et al. (2015) Rheological characterization of an injectable alginate gel system. BMC Biotechnol. 15, 29

41 Niu, R. et al. (2017) Hybrid pectin-Fe3+/polyacrylamide double network hydrogels with excellent strength, high stiffness, superior toughness and notch-insensitivity. Soft Matter 13, 9237-9245

$42 \mathrm{Hu}, \mathrm{H}$. et al. (2018) Three AtCesA6-like members enhance biomass production by distinctively promoting cell growth in Arabidopsis. Plant Biotechnol. J. 16, 976-988

43 Ivakov, A. et al. (2017) Cellulose Synthesis and Cell Expansion Are Regulated by Different Mechanisms in Growing Arabidopsis Hypocotyls. Plant Cell 29, 1305-1315

44 Roberts, A.W. et al. (2018) Functional Characterization of a Glycosyltransferase from the Moss Physcomitrella patens Involved in the Biosynthesis of a Novel Cell Wall Arabinoglucan. Plant Cell DOI: 10.1105/tpc.18.00082

45 Eklöf, J.M. and Brumer, H. (2010) The XTH Gene Family: An Update on Enzyme Structure, Function, and Phylogeny in Xyloglucan Remodeling. Plant Physiol. 153, 456-466

46 Deniaud-Bouët, E. et al. (2017) A review about brown algal cell walls and fucose-containing sulfated polysaccharides: Cell wall context, biomedical properties and key research challenges. Carbohydr. Polym. 175, 395-408 
47 Terauchi, M. et al. (2017) Genome-wide computational analysis of the secretome of brown algae (Phaeophyceae). Mar. Genomics 32, 49-59

48 Michel, G. et al. (2010) The cell wall polysaccharide metabolism of the brown alga Ectocarpus siliculosus. Insights into the evolution of extracellular matrix polysaccharides in Eukaryotes. New Phytol. 188, 82-97

49 Nardi, C.F. et al. (2015) Overexpression of the carbohydrate binding module of strawberry expansin2 in Arabidopsis thaliana modifies plant growth and cell wall metabolism. Plant Mol. Biol. 88, 101-117

50 Ye, N. et al. (2015) Saccharina genomes provide novel insight into kelp biology. Nat. Commun. 6, 6986

51 Proseus, T.E. and Boyer, J.S. (2007) Tension required for pectate chemistry to control growth in Chara corallina. J. Exp. Bot. 58, 4283-4292

52 Nolte, T. and Schopfer, P. (1997) Viscoelastic versus plastic cell wall extensibility in growing seedling organs: a contribution to avoid some misconceptions. J. Exp. Bot. 48, 21032107

53 Riquelme, M. et al. (2011) Architecture and development of the Neurospora crassa hypha a model cell for polarized growth. Fungal Biol. 115, 446-474

54 Al-Zube, L.A. et al. (2017) Measuring the compressive modulus of elasticity of pith-filled plant stems. Plant Methods 13, 99

55 Rabillé, H. et al. (2018) Dynamic and microscale mapping of cell growth: Case of Ectocarpus filament cells. In Protocols for Macroalgae Research pp. 349-364, Bénédicte Charrier, Thomas Wichard, C R K Reddy

56 Robinson, S. et al. (2017) An Automated Confocal Micro-Extensometer Enables in Vivo Quantification of Mechanical Properties with Cellular Resolution. Plant Cell 29, 2959-2973

57 Schopfer, P. (2006) Biomechanics of plant growth. Am. J. Bot. 93, 1415-1425

58 Taiz, L. (1984) Plant Cell Expansion: Regulation of Cell Wall Mechanical Properties. Annu. Rev. Plant Physiol. 35, 585-657

59 Vogler, H. et al. (2015) Measuring the Mechanical Properties of Plant Cell Walls. Plants 4, $167-182$

60 Zhang, T. et al. (2016) Spatial organization of cellulose microfibrils and matrix polysaccharides in primary plant cell walls as imaged by multichannel atomic force microscopy. Plant J. 85, 179-192 
61 Nakata, M.T. et al. (2018) High-Throughput Analysis of Arabidopsis Stem Vibrations to Identify Mutants With Altered Mechanical Properties. Front. Plant Sci. 9,

62 Aouar, L. et al. (2010) Morphogenesis of complex plant cell shapes: the mechanical role of crystalline cellulose in growing pollen tubes. Sex. Plant Reprod. 23, 15-27

63 Carpita, N.C. and Gibeaut, D.M. (1993) Structural models of primary cell walls in flowering plants: consistency of molecular structure with the physical properties of the walls during growth. Plant J. 3, 1-30

64 Carpita, N.C. and MacCann, M. (2000) The Cell Wall. In Biochemistry and Molecular Biology of Plants pp. 52-108, Buchanan BB, Gruissem W \& Jones RL (eds)

65 Raimundo, S.C. et al. (2017) $\beta-1,3-G l u c a n s$ are components of brown seaweed (Phaeophyceae) cell walls. Protoplasma 254, 997-1016

66 Salmeán, A.A. et al. (2017) Insoluble $(1 \rightarrow 3)$, ( $\rightarrow 4)-\beta$-D-glucan is a component of cell walls in brown algae (Phaeophyceae) and is masked by alginates in tissues. Sci. Rep. 7, 2880

67 La Barre, S. et al. (2010) The Halogenated Metabolism of Brown Algae (Phaeophyta), Its Biological Importance and Its Environmental Significance. Mar. Drugs 8, 988-1010

68 Fernandes, A.N. et al. (2012) Mechanical properties of epidermal cells of whole living roots of Arabidopsis thaliana: an atomic force microscopy study. Phys. Rev. E Stat. Nonlin. Soft Matter Phys. 85, 021916

Glossary

All related to the cell wall:

- Elasticity: refers to the ability of a material to recover its initial dimensions after deformation (once the stress is released). Reversible deformability.

- Extensibility (as defined by D. Cosgrove): The capacity of the cell wall to grow through cell wall loosening (remodelling) in response to a stress.

- Growth (or chemo-rheological expansion, as defined by [52]): The increase in surface area, resulting from either enhanced stress or a modification of the cell wall propensity for deformation due either to an increase in elasticity or plasticity, or to cell wall remodelling.

- Intrinsic mechanical properties: elasticity, visco-elasticity or plasticity of a material. Measurements of the intrinsic mechanical properties are performed either directly by 
intrusive equipment in contact with the biological material (e.g. nano-/micro-indentation), or indirectly by measuring strain on material undergoing external physical forces (creeping, stretching, osmotic pressure).

- Plasticity: refers to the irreversible deformation of the cell wall. This process has a temporal dimension and, therefore, plasticity may be taken for visco-elasticity when the dynamics of viscosity are very slow (i.e. much longer than observation time). Also confusingly named "irreversible elasticity" by some authors (e.g., [14]).

- Remodelling: Defined here as the process by which the arrangement of the various cell wall components interacting with each other is modified. Remodelling does not change the net chemical composition of the cell wall and does not necessarily modify its intrinsic mechanical properties, e.g., modification of the position of hydrogen bonds without modifying their number, resulting in unchanged elasticity. It is promoted by molecular remodelling factors: expansin, xyloglucan endotransglucosylase/hydrolase, redox reactions (e.g., cross-linking bonds in fungal cell wall polysaccharides; [53]) or finely tuned chemical cycles involving the interaction of calcium with polysaccharides (e.g., pectate distortion in green algae; [14]). The term 'cell wall loosening' is used for remodelling processes resulting in growth.

- Stiffness: The opposite of deformability (both elastic and plastic). Assessed using Instron strain measurement techniques, indentation (atomic force microscopy), cell compression, stretching devices, etc. [3,4,39].

286 Table 1: Techniques employed for the study of cell wall mechanics during expansion.

287 This table intends to illustrate the range of available techniques allowing the measurement of cell mechanical properties. The list is not exhaustive. The "Parameters" column uses the author's terminology, but the exact definition of parameters may be subject to subtle variations between authors. The "Reference" column mainly indicates reviews. The acquisition of accurate data of cell wall mechanics during growth should be performed using a technique that can take measurements i) on living organisms, ii) over a period of time in accordance with the dynamics of growth, iii) at the precise position of the cell surface where growth takes place, whatever the scale, 
294 iv) in the direction of expansion (mainly tangential position along the cell surface; z-axis is less 295 relevant); and that is v) adequate for 3D objects (e.g., AFM is sensitive to the orientation of the 296 contact plan, as in the dome of the pollen tube), vi) compatible with the mechanical properties of 297 the biological sample (e.g. biological materials, and especially the cell wall, do not behave as 298 linear elastic materials) and vii) able to measure the overall cell wall mechanical features, and not 299 only the superficial, outermost layer (e.g. nano-indentation). Literature cited: [3,9,16,39,54-61]. 300 


\begin{tabular}{|c|c|c|c|c|c|c|c|}
\hline $\begin{array}{l}\text { Underlying } \\
\text { Mechanical } \\
\text { basis }\end{array}$ & Scale & Technique & Parameters & $\begin{array}{c}\text { On Living } \\
\text { material } \\
\text { (non destructive) } \\
\end{array}$ & Benefit & Disadvantage & Reference \\
\hline \multirow{3}{*}{ Growth } & Organ / tissue & Size measurement & Geometry & yes & Non intrusive; Cheap & Average of several tissues / cells & {$[58]$} \\
\hline & Cell & Size measurement & Geometry & yes & Automation possible & Tissue accessibility & [58] \\
\hline & Cell Wall & Marker displacement & Local strain & yes & Resolution $<\mu \mathrm{m}$ & Cells adhesion required & {$[55]$} \\
\hline \multirow{15}{*}{$\begin{array}{l}\text { Intrinsic } \\
\text { mechanical } \\
\text { properties } \\
\text { (including } \\
\text { elasticity } \\
\text { and } \\
\text { plasticity) }\end{array}$} & \multirow{4}{*}{ Tissue } & Extensometer & Wall loosening & yes & $\begin{array}{l}\text { Long-lasting experiments } \\
\text { Wide parameter range }\end{array}$ & $\begin{array}{l}\text { Indirect } \\
\text { Requires precise cutting } \\
\text { Low spatial resolution } \\
\text { Averaged data }\end{array}$ & {$[58]$} \\
\hline & & $\overline{\text { Osmotic pressure shift }}$ & Elongation kinetics & yes & Mimics natural conditions & Low resolution & [16] \\
\hline & & $\begin{array}{l}\text { Resonance frequency } \\
\text { (vibration) }\end{array}$ & $\begin{array}{l}\text { Stiffness } \\
\text { Damping coefficient }\end{array}$ & yes & $\begin{array}{l}\text { High-throughput } \\
\text { Non-destructive }\end{array}$ & Large scale, indirect & {$[61]$} \\
\hline & & Pressure-block & Stress relaxation & yes & Precise control & Indirect & 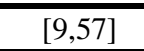 \\
\hline & \multirow{2}{*}{\multicolumn{2}{|c|}{ Extensometer (instron) }} & $\begin{array}{l}\text { Compressive } \\
\text { modulus of elasticity }\end{array}$ & yes & Overall figure at the cell level & $\begin{array}{l}\text { Requires precise cutting } \\
\text { Low spatial resolution }\end{array}$ & {$[54]$} \\
\hline & & & $\begin{array}{l}\text { Plastic compliance } \\
\text { Creep }\end{array}$ & no & $\begin{array}{l}\text { Wide range, in the plane of growth, } \\
\text { both elasticity and plasticity }\end{array}$ & & [9] \\
\hline & \multirow{8}{*}{ Cellular } & $\begin{array}{l}\text { Micro-extensometer } \\
\text { (ACME) }\end{array}$ & $\begin{array}{l}\text { Elasticity } \\
\text { Plasticity }\end{array}$ & yes & $\begin{array}{l}\text { Microscale, 3D, automated, } \\
\text { In the plane of growth } \\
\text { Both elasticity and plasticity }\end{array}$ & $\begin{array}{l}\text { Sophisticated equipment, } \\
\text { Very recent }\end{array}$ & {$[56]$} \\
\hline & & Creep measurement & Plastic yield stress & no & & $\begin{array}{l}\text { Stress-strain } \\
\text { Not only CW properties }\end{array}$ & [9] \\
\hline & & Micro-manipulation & \multirow{2}{*}{ Elasticity } & yes & & Artificial samples & {$[9]$} \\
\hline & & Ball tonometry & & yes & Overall figure at the tissue level & Low spatial resolution & [39] \\
\hline & & Relaxation spectra & Stress relaxation & yes & Wide parameter range & Requires data smoothing & [9] \\
\hline & & Mercury inflatation & $\begin{array}{l}\begin{array}{l}\text { Multiaxial plastic } \\
\text { extensibility }\end{array} \\
\text { Creep recovery } \\
\end{array}$ & no & & Intrusive; hazardous & {$[58]$} \\
\hline & & $\begin{array}{l}\text { Microfluidics } \\
\text { ("lab-on-a-chip") }\end{array}$ & $\begin{array}{l}\text { Compression } \\
\text { potential }\end{array}$ & yes & $\begin{array}{l}\text { Continuous measurements with vary- } \\
\text { ing growth conditions } \\
\text { Automation possible }\end{array}$ & $\begin{array}{l}\text { Low spatial resolution } \\
\text { Artificial environment }\end{array}$ & {$[3,59]$} \\
\hline & & $\begin{array}{l}\text { Inflation/deflation (osmo- } \\
\text { tic changes) }\end{array}$ & $\begin{array}{l}\text { Elastic modulus } \\
\text { (linearity) }\end{array}$ & yes & Easy to design & $\begin{array}{l}\text { Approximate } \\
\text { Mainly 2D only }\end{array}$ & [9] \\
\hline & Cell Wall & Extensometer (instron) & Elastic compliance & no & $\begin{array}{l}\text { Wide range } \\
\text { Both elasticity and plasticity }\end{array}$ & $\begin{array}{l}\text { Requires precise cutting } \\
\text { Low spatial resolution }\end{array}$ & {$[9,57]$} \\
\hline
\end{tabular}




\begin{tabular}{|c|c|c|c|c|c|}
\hline $\begin{array}{l}\text { Cellular force microscopy: } \\
\text { indentation }\end{array}$ & Cell wall stiffness & yes & $\begin{array}{l}\text { High resolution } \\
\text { Relatively high forces }(\mu \mathrm{N})\end{array}$ & Complex equipment & [16] \\
\hline $\begin{array}{l}\text { Atomic force microscopy: } \\
\text { micro-indentation }\end{array}$ & \multirow{2}{*}{$\begin{array}{l}\text { Stiffness, } \\
\text { Elasticity, } \\
\text { Plasticity, } \\
\text { Adhesion }\end{array}$} & yes & $\begin{array}{l}\text { High spatial resolution ( } \mu \mathrm{m} \text { scale) } \\
\text { Surface mapping } \\
\text { Outer and inner cell wall layers } \\
\text { Possible in aquaous medium }\end{array}$ & $\begin{array}{l}\text { Complex equipment } \\
\text { In z-axis (not the growth plane) } \\
\text { Sensitive to indentation angle } \\
\text { Requires adherent sample }\end{array}$ & {$[3,16,38]$} \\
\hline $\begin{array}{l}\text { Atomic force microscopy: } \\
\text { nano-indentation }\end{array}$ & & yes & $\begin{array}{l}\text { High spatial resolution (nm scale) } \\
\text { Surface mapping, low force (nN) } \\
\text { possible in aquaous medium }\end{array}$ & $\begin{array}{l}\text { Complex equipment } \\
\text { In z-axis } \\
\text { Only outer cell wall layer } \\
\text { Sensitive to indentation angle } \\
\text { Requires adherent samples }\end{array}$ & {$[3,60]$} \\
\hline $\begin{array}{l}\text { Dynamic nanoindentation } \\
\text { (nanoDMA) }\end{array}$ & $\begin{array}{l}\text { Viscoelasticity } \\
\text { Storage/loss stiffness }\end{array}$ & yes & $\begin{array}{l}\text { High resolution (nanoscale) } \\
\text { Can be coupled to TEM and SEM }\end{array}$ & Requires sophisticated equipment & [9] \\
\hline Uniaxial stress & $\begin{array}{l}\text { Mechanical } \\
\text { anisotropy }\end{array}$ & no & & Intrusive & {$[58]$} \\
\hline
\end{tabular}


303 Table 2: Cell wall components of land plants and brown algal cell walls

304 Table shows the nature and approximate abundance (\% dry weight) of the different components of

305 the cell wall in land plants (only primary cell wall; both dicotyledonous and monocotyledonous

$306[33,62-64])$ and in brown algae [46,65-67]. * Much higher abundance in Poales

307 (monocotyledonous).

308

\begin{tabular}{|c|c|c|c|}
\hline \multirow{2}{*}{ Class } & \multirow{2}{*}{ Sub-class } & \multicolumn{2}{|c|}{ Abundance } \\
\hline & & Land plants & Brown algae \\
\hline Cellulose & No sub-class & $15-33 \%$ & $1-8 \%$ \\
\hline \multirow{13}{*}{ Hemicelluloses } & Homoxylans (X) & \multirow{4}{*}{$\sim 8 \%$} & \\
\hline & Arabinoxylans (AX) & & \\
\hline & Glucuronoxylans (GX) & & \\
\hline & Glucuronoarabinoxylans (GAX) & & \\
\hline & Xyloglucans (XyG) & $\sim 20 \%$ & \\
\hline & Xyloglucuronans & & Present \\
\hline & Mannans (M) & Scarce & \\
\hline & Glucomannans & Scarce & \\
\hline & Galactomannans & Scarce & \\
\hline & Galactoglucomannans & Scarce & \\
\hline & Glucuronomannans & Scarce & \\
\hline & Mixed-linkage-glucans (MLG) & Scarce* & Present \\
\hline & Callose $(\beta-1,3$-glucans $)$ & Potentially abundant & Present \\
\hline \multirow{5}{*}{ Pectins } & Homogalacturonnans (HG) & $6-15 \%$ & \\
\hline & Rhamnogalacturonans I (RGI) & $5-10 \%$ & Present \\
\hline & Rhamnogalacturonans II (RGII) & $1-4 \%$ & \\
\hline & Apiogalacturonans & Scarce & \\
\hline & $=\underline{\text { Xylogalacturonans }}$ & Scarce & \\
\hline Alginates & No sub-class & & $\sim 40 \%$ \\
\hline \multirow{5}{*}{$\begin{array}{l}\text { Fucose-Containing } \\
\text { Sulphated Polysaccharides } \\
\text { (FCSP) }\end{array}$} & Fucans & & \multirow{5}{*}{$\sim 40 \%$} \\
\hline & Fucoglucuronans & & \\
\hline & Fucogalactans & & \\
\hline & Xylofucoglucuro-mannans & & \\
\hline & $=$ Uncharacterised FCSPs & & \\
\hline \multirow{3}{*}{$\begin{array}{l}\text { Non-catalytic } \\
\text { remodeling proteins }\end{array}$} & Expansins & Present & \\
\hline & YoaJ-like proteins & & Present \\
\hline & $=\overline{\text { CBM32-containing proteins }}$ & & Present \\
\hline \multirow{9}{*}{ Catalytic remodeling proteins } & Glucosidases & Present & \\
\hline & Glucanases & Present & \\
\hline & B-galactosidases & Present & \\
\hline & Polygalacturonases (PGs) & Present & \\
\hline & $\begin{array}{l}\text { Pectate-lyases (PLs) and } \\
\text { Pectase-lyase-like (PLLs) }\end{array}$ & Present & \\
\hline & Xyloglucan EndoTransglycosidases (XETs) & Present & \\
\hline & Xyloglucan endo-hydrolases (XEH) & Present & \\
\hline & Xylosidases & Present & \\
\hline & Pectin-Methyl-Esterases (PMEs) & Present & \\
\hline
\end{tabular}




\begin{tabular}{|c|c|c|c|}
\hline & \multirow{2}{*}{\multicolumn{2}{|c|}{ And PME-Inhibitors (PMEIs) }} & \\
\hline & & & \\
\hline & Pectin acetylesterases & Present & \\
\hline & Xyloglucan acetylesterases & Present & \\
\hline & Mannuronate-C5-Epimerases & & Present \\
\hline & $\begin{array}{l}\text { Vanadate-dependant } \\
\text { Halogenoperoxidases (vHPO) }\end{array}$ & & Present \\
\hline & GH88-familiy proteins & & Present \\
\hline & Alginate-lyases & & Present \\
\hline & $\begin{array}{l}\text { Pectin-lyase-fold } \\
\text { Virulence factor domain proteins }\end{array}$ & & Present \\
\hline & $\begin{array}{l}\text { Metalloproteinases and inhibitors } \\
\text { (TIMP)-like proteins }\end{array}$ & & Present \\
\hline & Subtilisin-like serine proteases & & Present \\
\hline & CBM1-containing proteins & & Present \\
\hline \multirow{5}{*}{ Structural proteins } & Arabinogalactan Proteins (AGPs) & Present & Present \\
\hline & $\begin{array}{l}\text { Prolin-Rich Proteins (PRPs) } \\
\text { (PRs }\end{array}$ & Present & \\
\hline & $\begin{array}{l}\text { Hydroxyprolin-rich proteins (HPRPs) } \\
\text { including Extensins }\end{array}$ & Present & \\
\hline & Glycin-rich proteins (GRPs) & Present & Present \\
\hline & $\begin{array}{l}\text { Many uncharacterised } \\
\mathrm{CW} \text { proteins }\end{array}$ & Present & $5-9 \%$ \\
\hline \multirow{2}{*}{ Phenolic compounds } & Para-coumaryl acid & $>2 \%$ & \\
\hline & Phlorotannins & & Present \\
\hline
\end{tabular}

\section{Figure legends}

313 Figure 1: Cell wall mechanical properties involved in cell wall expansion

314 Growth involves cell wall yielding, either in response to increased tensile stress (not considered

315 here) and/or in response to an increase in the cell wall amenability to expand (shown here). The

316 thick grey border represents the cell contour following cell wall growth. Colour boxes represent

317 the relative part played by either the intrinsic mechanical properties (blue) or remodelling (green)

318 in cell wall growth. The resting state is represented, by default, with boxes of equal areas. (A)

319 Intrinsic mechanical properties are modified to allow cell growth. Among them, elasticity can

320 promote growth due to the activity of enzymes (e.g., pectin-methylesterase inhibitor in the pollen

321 tube in Angiosperms, which maintains inactive PME and methyl-esterified pectins in the growing

322 tip). Using nano- and micro-indentation techniques (Table 1), elasticity has been shown to be

323 involved in the growth of many plant, algal and fungal cells (see text for references). However,

324 the reliability of nano- and micro-indentation is questioned. The involvement of 'true' cell wall

325 intrinsic plasticity has been debated [52], because it is often confused with visco-elasticity.

326 Analyses of indentation curves require more complicated models to infer quantitative data on the 
propensity of the cell wall to plasticity (hysteresis, [68]). (B) Cell wall remodelling factors (e.g., 328 expansin, xyloglucan endo-transglycosylase) displace the load-bearing bonds between components without modifying the overall chemical composition of the cell wall (e.g., expansins modify the bonds between cellulose and hemicellulose), thereby promoting growth. For example,

331 in the green alga Chara, diffuse growth of the internodes relies on the cycling of distorted to non-

332 distorted calcium-pectate complexes in new cell walls and calcium delivery to the cell membrane 333 [14]. Dynamics in this cycle results in windows of increased cell wall elasticity and growth. (C) 334 In the brown alga Ectocarpus, a treatment with $1 \mu \mathrm{M}$ latrunculin $\mathrm{B}$ resulted in an increase in 335 growth whereby the cell increased its width significantly. Simultaneously, the cell lost its capacity 336 to swell in response to a hypo-osmotic shock, meaning that its intrinsic elasticity (and potentially 337 plasticity) was reduced (unpublished data from the authors).

339 Figure 2. Comparison of the cell wall chemical composition and structure in land plants and 340 brown algae.

341 Only the primary cell wall is considered. (A) In land plants (Angiosperms), the cell wall is mainly composed of two networks: (i) cellulose microfibrils (MFs, both crystalline and non-crystalline 343 [62]) which are cross-linked by hemicelluloses chains (for simplicity only xyloglucans, XG, are 344 represented in the drawing) via hydrogen bonds, and (ii) pectin gel network. Pectins are composed of several sub-structures: homogalacturonan (HG) and rhamnogalacturonan I and II (RGI and II). Demethylesterified HGs are crosslinked by calcium ions and RGII are cross-linked by borate. Extensins, which are structural proteins potentially cross-linking cellulose and pectins, 348 and arabinogalactan proteins (AGP) are also shown, although their detailed structure and interaction are not certain $[63,64]$. For a detailed review on the composition of the cell wall of the pollen tube, see [33]. (B) In brown algae, much less is known about the detailed composition and structure of the cell wall compared with land plants. The model presented here is mainly based on 352 [47]. The cell wall is likely composed of at least two independent networks: (i) cellulose MFs 353 cross-linked with fucose-containing sulphated polysaccharides (FCSPs) and proteins, and (ii) 354 alginate gel networks cross-linked by phlorotannins. Cellulose MFs are ribbon-shaped and much 355 less abundant than in land plant cell walls (0-8\% dry weight, Table 2). For simplicity, only 356 homofucans FCSPs are represented in the drawing. The identity and structure of putative cross357 linking proteins (in blue, including recently identified AGPs) and phlorotannins are speculative. $358 \beta$ - $(1 \rightarrow 3)$-glucans (callose) and $\beta-(1 \rightarrow 3)-(1 \rightarrow 4)$-glucans (mixed-linkage glucans, MLG, not 
359 shown in the drawing) have also been identified in brown algal cell wall (Table 2), but their 360 interactions with other components are unknown $[65,66]$. The cell wall of brown algae is also rich 361 in halogenated compounds (up to $19 \% \mathrm{dw}$ ), especially iodine species in the form of free ions (up 362 to $1.0 \%$ dw, i.e. 30,000 -fold the concentration of the seawater) or included in halogenated 363 molecules (especially phlorotannins, [67]). All components are drawn to scale. 


\section{MECHANICS OF GROWTH}

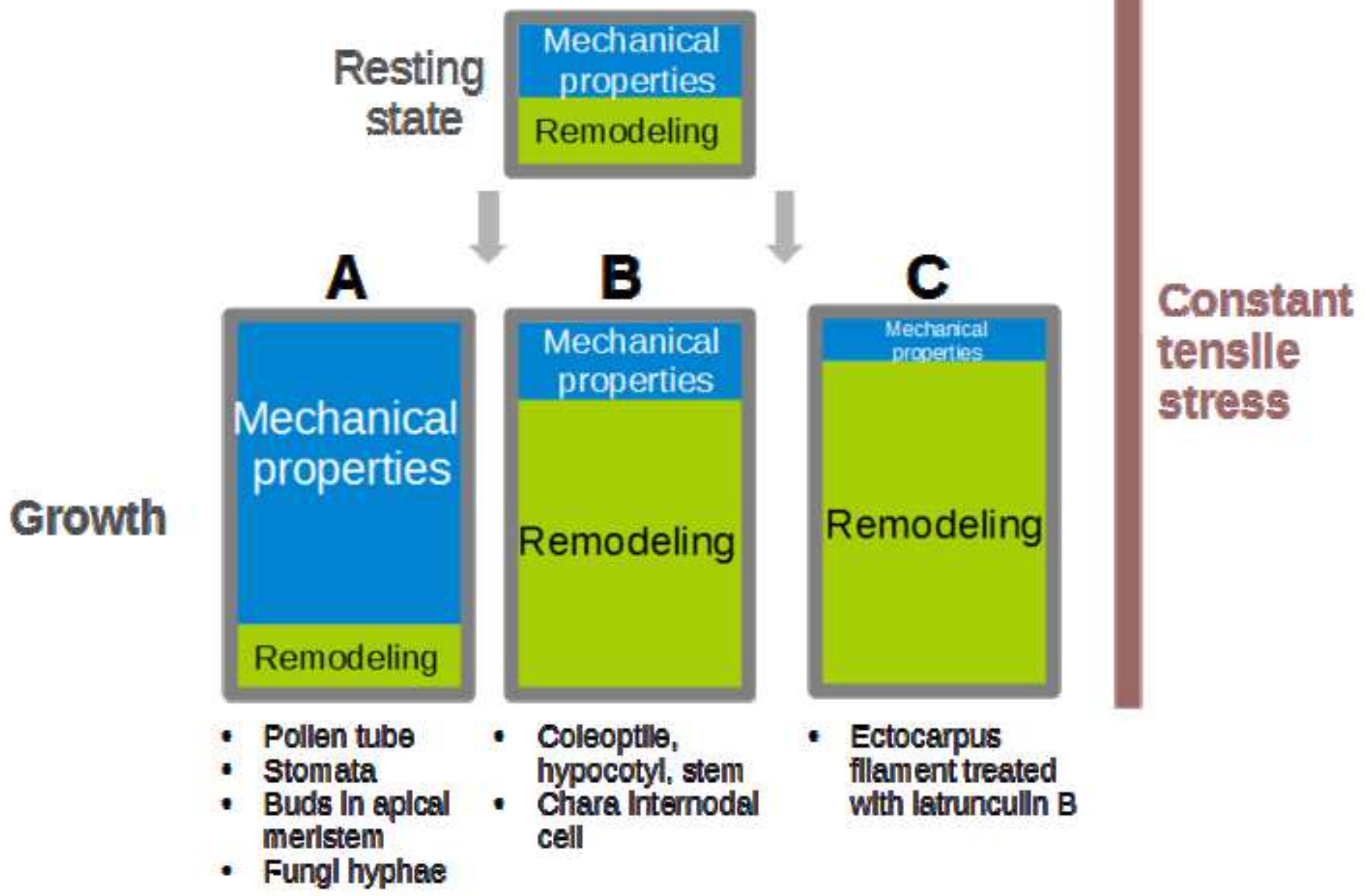




\section{Figure 2}

A

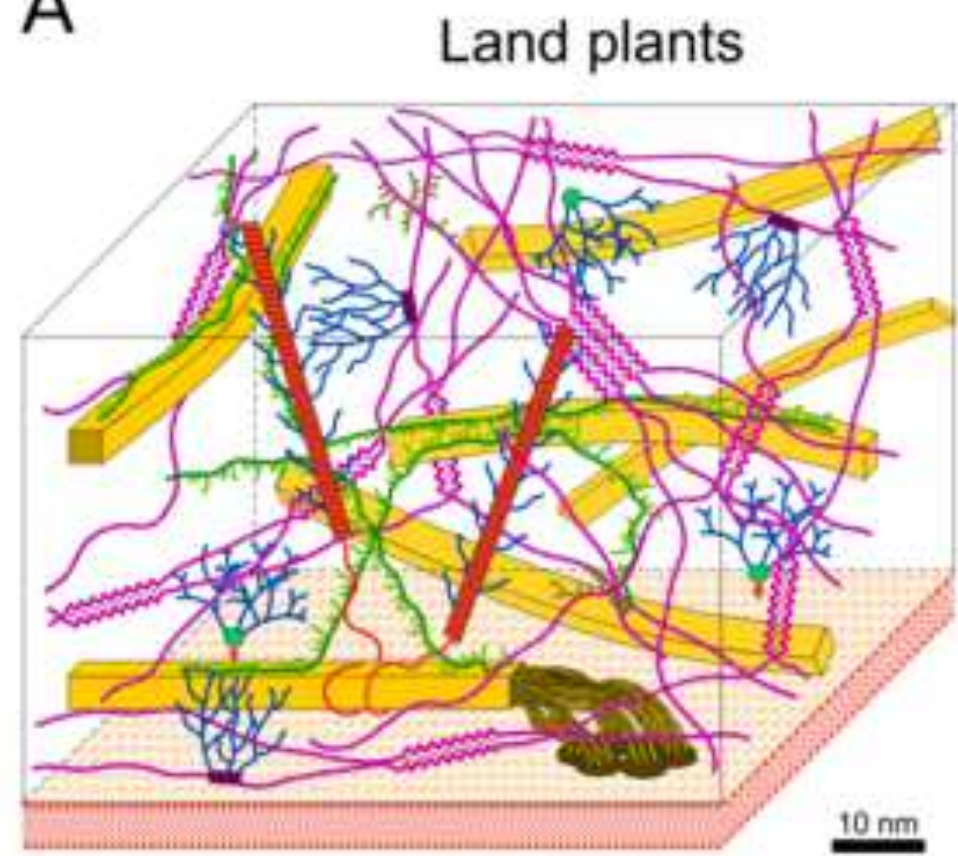

B
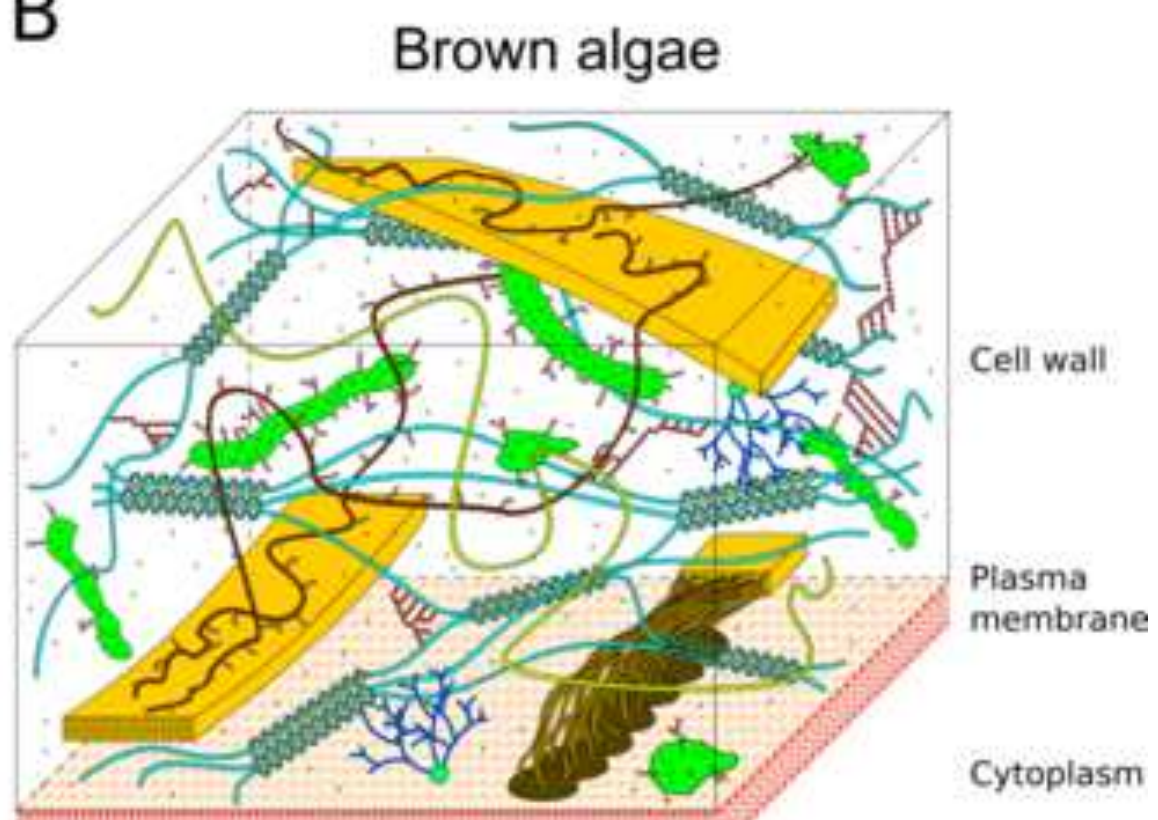

- Methylestunified homogalacturonan

\#w Demethylesterified homogalacturonan cross-linked by $\mathrm{Caz}^{*}$ 37 Rhaminogalacturonan ( (RG) with arabinogalactan sidochains W) Phamnogalacturonain II (RGE) with its four characteristic side chains jubre Covalent boron cross-link between two side-chains A

शे Extensin with arabinoside side-chains

T. Glycosylphosphatidytinoshol (GP) ancher for membrane-bound AGP
A. Homolucans with short side-chains

Alginates, MM- or MC-blocks

WOXSO Alginates, GG-blocks cross-linked by $\mathrm{Ca}^{2+}$ icns

j. Putative structural protein in brown algai cell wall bound is phlorotarnins

\$* " Phiorotannins

- lodine 


\section{Highlights}

- There is a current overwhelming paradigm of cell growth that promotes one main scenario: intrinsic elasticity or plasticity of the cell wall control growth.

- In brown algae, which evolved independently from land plants and fungi, both the structure and the chemical composition of the cell wall differ from their counterparts.

- Beyond the complete inventory of cell wall components, their proportion and potential chemical modifications and interactions (covalent, electrostatic) with each other are still largely unknown, even in the most studied organisms, such as land plants.

- Data on land plants and brown algae show that cell wall propensity to grow does not systematically depend on the intrinsic mechanical properties of the cell wall.

- Complexity and diversity of cell wall compositions and structures make preconceived transposition of cell wall growth mechanisms hazardous. 


\section{Outstanding questions}

- What are the molecular bases of elasticity in brown algal cell wall, considering its specific composition?

- What is the molecular toolkit of cell wall remodelling in brown algae? Do proteins with similar functions as expansins exist?

- How easily can distinct yet overlapping roles be considered for the cell wall in the lifespan of a cell ? For example, can swelling in response to hypo-osmotic shock rely on mechanical properties or chemical components involved in the cell wall expansion process taking place during growth?

- Are current technical tools suitable to measure the relevant cell wall physical constants involved in growth ? Especially when several cell wall layers are involved ?

- Can cell wall mechanical properties measured at small time-scale be relevant for understanding processes occurring at long-time scale, typical of cell growth?

- To what extent can results obtained on model land plants be transposed to other species ? Which features should be common ? Chemical components, supramolecular structure and organization or intrinsic mechanical properties regardless of the chemical composition? 